\title{
Trophoblast Invasion and Placentation: Molecular Mechanisms and Regulation
}

Frédéric van den Brûle ${ }^{\mathrm{a}, \mathrm{b}}$, Sarah Berndt ${ }^{\mathrm{a}}$, Nadine Simon ${ }^{\mathrm{a}}$, Capucine Coulon ${ }^{\mathrm{a}}$, Jeanne Le Goarant ${ }^{\mathrm{a}}$, Carine Munaut $^{\mathrm{a}}$, Agnès Noël ${ }^{\mathrm{a}}$, Francis Frankenne ${ }^{\mathrm{a}}$, Jean-Michel Foidart ${ }^{\mathrm{a}, \mathrm{b}}$

${ }^{a}$ Laboratory of Tumor Biology and Development, Pathology B23 and ${ }^{b}$ Department of Gynecology and Obstetrics, CHU Liège, Liège, Belgium

\begin{abstract}
Trophoblast invasion is a key process during human placentation. This event constitutes the basis of the conversion of the uterine spiral arteries, a process which allows an adequate vascular connection between the intervillous space and the maternal blood flow. Trophoblast invasion is transient, with stringent spatial and temporal control. Preeclampsia, a leading cause of maternal and fetal mortality and morbidity, is associated with decreased, shallow trophoblastic invasion. In this article, we review the molecular mechanisms of trophoblast invasion, and its mechanisms of regulation. Insights into the etiopathogenesis of preeclampsia will also be
\end{abstract} detailed.

\section{INTRODUCTION}

Implantation of the human egg occurs 6-7 days after conception. This process probably includes three stages. Apposition, the initial adhesion of the blastocyst to the uterine wall, usually occurs at the upper posterior wall of the uterus. Then stable adhesion of the blastocyst to the endometrium occurs. This event is followed by invasion of the decidua. At this moment, the embryonic pole of the blastocyst is oriented towards the uterine epithelium [1].

Trophoblast cells are derived from the trophoectoderm of the blastocyst. These cells adhere to the endometrium and initiate the process of implantation. During the first trimester of gestation, cytotrophoblast (CTB) stem cells reside in two types of chorionic villi, namely floating and anchoring villi. The CTBs can differentiate according to two distinct pathways, giving rise to two trophoblast populations that are morphologically and functionally distinct [2-5].

Fig. 1: Placental bed of a normal human pregnancy, 13 weeks of gestation. Intermediate trophoblasts (immunostained for cytokeratin, brown color, upper right part of the picture) invade the decidua close to a maternal artery (A).

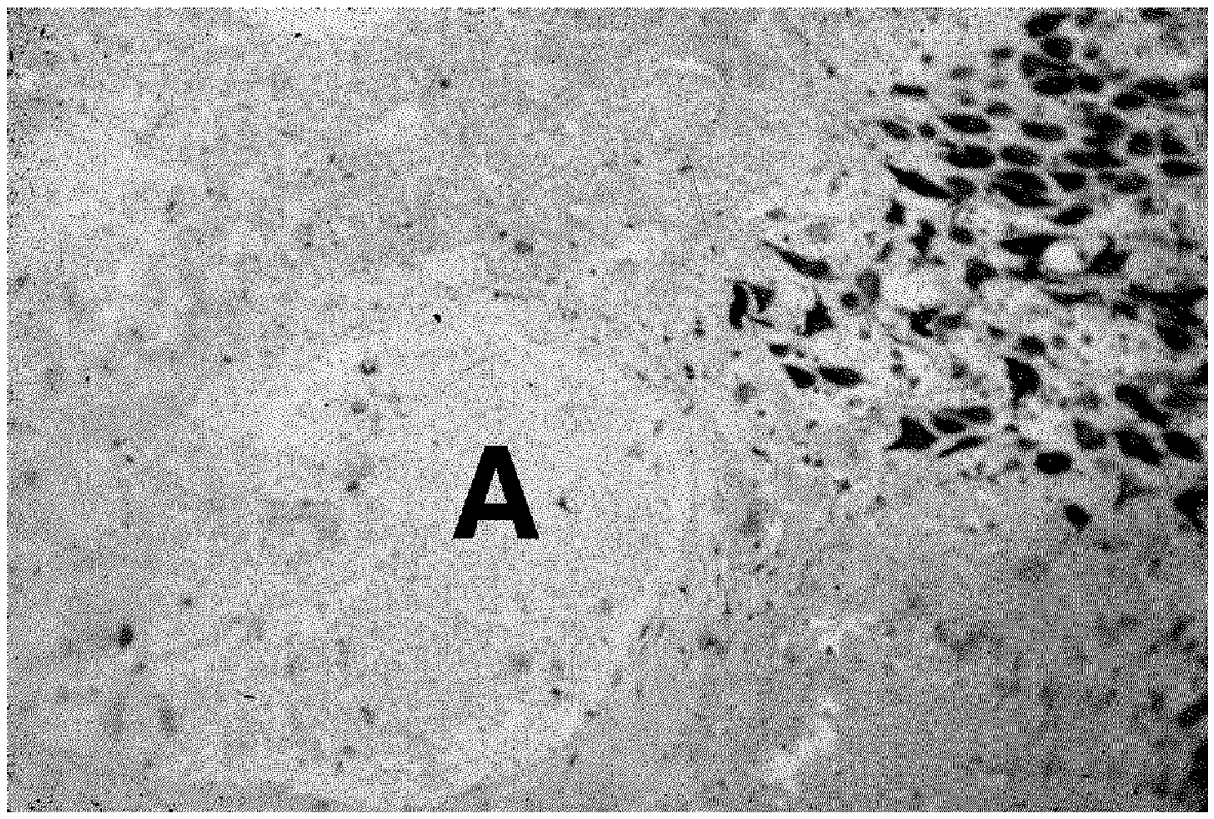


Floating villi do not contact the uterine wall. In these villi, CTBs consist of a polarized epithelial monolayer, anchored to a basement membrane and surrounding a stromal core containing fetal blood vessels. These CTBs highly proliferate during the first trimester of gestation and differentiate exclusively by forming a multinucleated syncytium called syncytiotrophoblast (STB) that covers the villi. Floating villi are bathed by maternal blood and perform gas and nutrient exchange functions for the developing embryo. STBs also produce placental hormones and growth factors.

Anchoring villi contain CTB stem cells that enter both pathways of differentiation. In much of the anchoring villus, CTB fuse to form STB. At day 10, the blastocyst is completely embedded into the stroma of the uterus, and CTBs break through the syncytial layer and form multilayered columns of nonpolarized cells. Anchoring villi, via these columns, physically connect the embryo to the uterine wall and are the source of the most highly invasive CTBs, the intermediate trophoblasts [6-8], found in the pregnant endometrium (decidua) and the first third of the myometrium, collectively designated the placental bed (fig. 1). A subpopulation of the intermediate trophoblasts invades the uterine blood vessels (endovascular invasion; fig. 2), a process which establishes adequate perfusion of the placenta $[9,10]$. The endovascular trophoblasts migrate to the uterine spiral arteries, where they replace the endothelial cell lining and the muscular and elastic layer of these arteries. This process, named conversion, occurs during the first trimester of pregnancy, and leads to low-resistance, high-capacitance blood vessels that allow for adequate blood flow during the pregnancy.

Fig. 2: Normal uteroplacental artery, 14 weeks of gestation. The arterial wall is invaded by trophoblastic cells (immunostained for cytokeratin) who replace the media and endothelium.

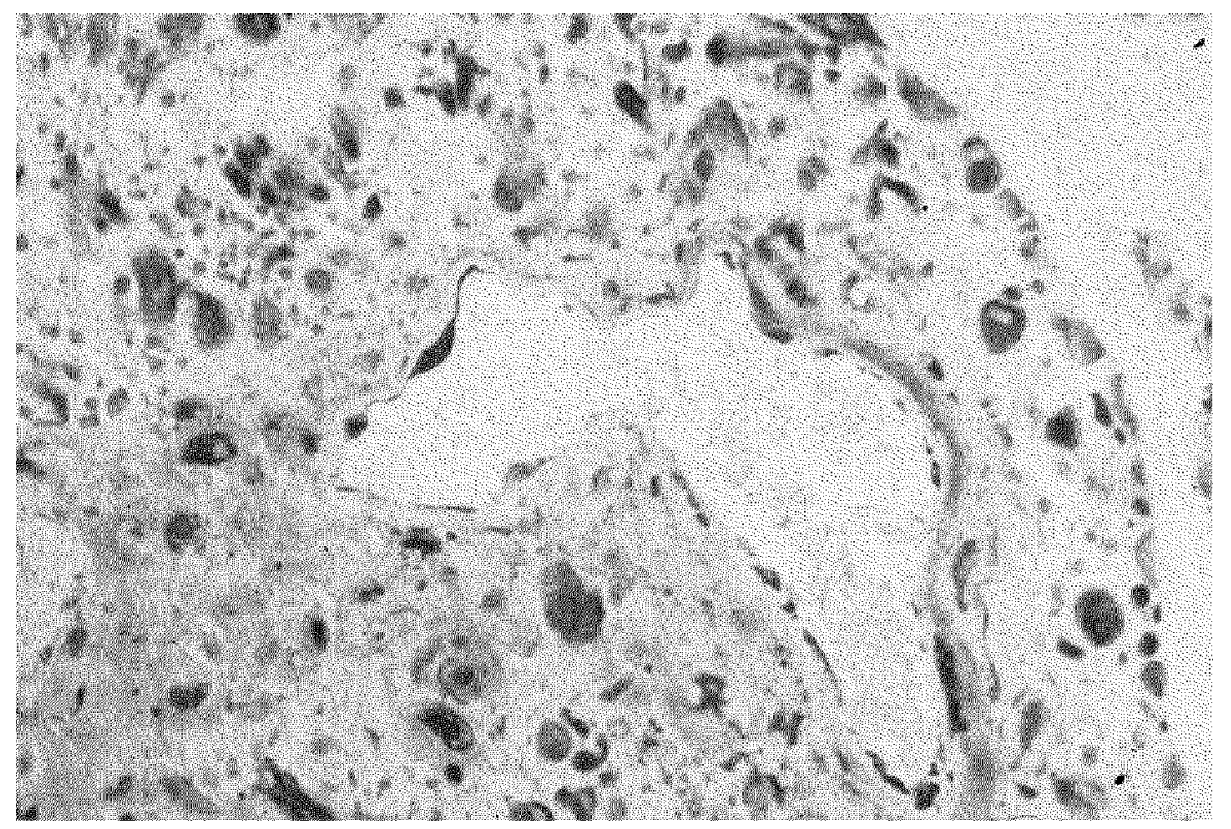

The process of anchoring villus formation and related CTB invasion of the uterine wall is extremely active during the first trimester of gestation. The morphology of the placenta is quite similar at the first and second trimester. During the third trimester, cell columns are no longer visible.

Many aspects of trophoblast invasion are thought to be similar to events that occur during tumor cell invasion, when an in situ lesion becomes an invasive carcinoma, i.e. when cells penetrate an epithelial basement membrane and invade the underlying stroma [11]. Like malignant tumor invasion of the host tissue, trophoblast invasion of the maternal uterus is a multistep process. It involves attachment of the trophoblastic cells to the extracellular matrix (ECM) components, degradation of the ECM and migration through the connective tissue defect [5]. However, unlike tumor invasion, trophoblast invasion of the decidua is precisely regulated, confined spatially to the uterus and temporally to early pregnancy.

Dysregulation of trophoblast invasion is associated with various pathological problems. Indeed, excessive invasion can lead to placenta accreta, increta or percreta [12] that constitute leading causes of postpartal hemorrhage.

Uncontrolled trophoblast invasion can also lead to choriocarcinoma with possible metastases [13]. 
On the other hand, inadequate trophoblast invasion is associated with preeclampsia. This entity is characterized by maternal edema, pregnancy-induced hypertension and proteinuria, and, in severe cases, eclampsia and abruptio placenta. Preeclampsia is associated with significant maternal and fetal death [12]. It is caused by limited trophoblastic invasion and a failure to convert the spiral arteries. This leads to the conservation of the reactivity of the maternal arteries to vasoconstrictive agents, resulting in placental hypoxia. Another entity associated with placental abnormalities and reduction of trophoblast invasion is intrauterine growth retardation.

In-depth understanding of the molecular mechanisms that underlie trophoblast invasion could help understand the etiopathogenesis of diseases like preeclampsia and intrauterine growth retardation. It could also constitute the basis for new innovative therapeutic strategies for these diseases. In this article, we review the molecular mechanisms of trophoblastic invasion.

\section{ADHESION MOLECULES}

Adhesion of various types of cells are mediated through specific cell surface receptors designated integrins. These receptors are heterodimeric $\alpha \beta$-type transmembrane glycoproteins. Their specificity of binding depends on the type of $\alpha / \beta$ combination. CTBs express integrins to adhere to ECM components, and modulate their integrin repertoire when they invade the mother tissues (table 1) [14, 15]. Examination of first trimester placenta $[14,16]$ and of an in vitro model of Matrigel invasion by CTBs [15] reveals that the invasion of CTBs leads to a decreased expression of adhesion receptors characteristic of CTB stem cells, and an increase in the expression of adhesion receptors that are characteristic of vascular cells.

Indeed, villous CTBs predominantly express the $\alpha 6 \beta 4$ integrin, a laminin receptor. In contrast, the invasive extravillous CTBs present with a differentially modulated integrin repertoire. Columnar CTBs express $\alpha 6 \beta 4$ in a nonpolarized fashion; more distal, placental bed-invasive CTBs express $\alpha 5 \beta 1$ integrin, a fibronectin receptor. Interstitial and endovascular CTBs also express $\alpha 1 \beta 1$, a laminin and collagen receptor $[14,15]$. This profile of integrin expression is also observed on CTBs that invade Matrigel [15]. The importance of these adhesion molecules has been highlighted by in vitro experiments. Antibody perturbation of the interactions involving $\alpha 1 \beta 1$, type IV collagen and laminin inhibits CTB invitro invasion, whereas perturbing interactions between fibronectin and $\alpha 5 \beta 1$ promoted invasion [15].

Table 1: Expression of adhesion molecules and integrins in first trimester trophoblast [data from 14, 17, 23-26, 117]

\begin{tabular}{|c|c|c|c|c|c|c|}
\hline & $\begin{array}{c}\text { Zone I } \\
\text { villous CTB }\end{array}$ & $\begin{array}{c}\text { Zone II } \\
\text { column CTB } \\
\text { proximal }\end{array}$ & $\begin{array}{c}\text { Zone III } \\
\text { column CTB } \\
\text { distal }\end{array}$ & $\begin{array}{c}\text { Zone IV } \\
\text { placental bed } \\
\text { CTB } \\
\text { interstitial }\end{array}$ & $\begin{array}{c}\text { Zone V } \\
\text { placental bed } \\
\text { CTB } \\
\text { endovascular }\end{array}$ & $\begin{array}{c}\text { maternal } \\
\text { ECs }\end{array}$ \\
\hline$\alpha 1$ & - & - & - & + & + & \pm \\
\hline$\alpha 4$ & - & + & + & + & + & \pm \\
\hline$\beta 1$ & \pm & \pm & + & + & + & + \\
\hline$\beta 3$ & - & - & + & + & + & + \\
\hline$\beta 4$ & + & + & \pm & - & - & - \\
\hline$\beta 5$ & + & - & - & - & - & - \\
\hline$\beta 6$ & \pm & \pm & - & - & - & - \\
\hline E-cadherin & + & + & \pm & \pm & - & - \\
\hline VE-cadherin & - & + & + & + & + & + \\
\hline$\alpha \mathrm{V} \beta 3$ & - & - & - & + & + & + \\
\hline VCAM-1 & - & \pm & + & + & + & \pm \\
\hline PECAM-1 & - & - & + & + & + & + \\
\hline NCAM-1 & - & - & - & - & + & \\
\hline CEACAM-1 & - & + & \pm & \pm & \pm & \\
\hline MCAM & - & + & + & + & + & \\
\hline E-selectin & + & + & + & + & + & \pm \\
\hline L-selectin & + & + & + & + & + & \\
\hline
\end{tabular}

Zone I - Monolayer of CTB on the trophoblast basement membrane; zones II and II - cell aggregate (column) formed by differentiating $\mathrm{CTB}$; zone IV = interstitial trophoblasts that have invaded the maternal decidua; zone $\mathrm{V}=$ endovascular trophoblasts and placental bed CTBs. 
The CTBs also undergo an epithelial to endothelial cell transformation. Indeed, they decrease E-cadherin, and increase endothelial-specific adhesion molecules, such as VE-cadherin, PECAM-1 and VCAM-1 [17-20]. They also express various vasodilatory and anticoagulative factors [21]. Functional studies using blocking antibodies reveal that $\alpha \mathrm{V} \beta 3$ and VE-cadherin enhance, and E-cadherin decreases CTB invasion [17].

Examination of placenta from the second and third trimester of gestation revealed similar patterns of integrin expression with only slight differences [16]. Indeed, during the second trimester, the $\alpha 3$ integrin subunit is detected on villous CTBs, columns and placental bed CTBs. Third trimester floating villi are characterized by persisting expression of the $\alpha 6$ integrin subunit, whereas $\beta 4$ is not detected.

Fig. 3: Immunohistochemical localization of galectin-3 in a first trimester galectin-3 expression when polarized CTBs (arrows) differentiate to form the trophoblastic cell column (TCC). $S=$ Villous stroma.

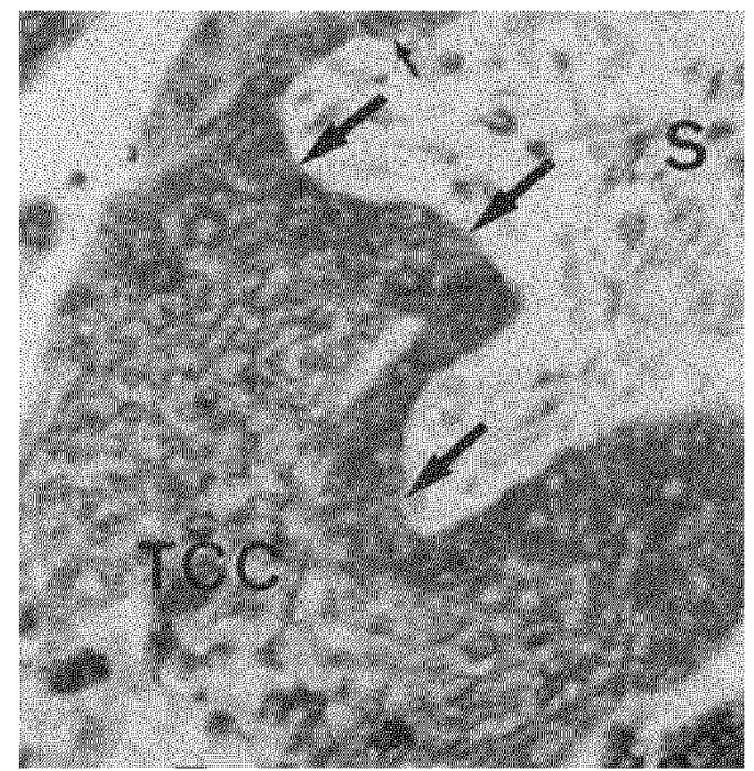

The focal adhesion kinase (FAK), which is implicated in signal transduction after binding of the ligand on integrins, is expressed by CTBs in all stages of differentiation [22]. Autophosphorylation on tyrosine 397 (Y397FAK) is only detected in a subset of invasive CTBs near the surface of the uterine wall. It appears to mediate CTB invasion, as antisense FAK induces a striking reduction of in vitro invasion [22].

Other adhesion molecules are differentially expressed during trophoblast differentiation and invasion. For instance, the adhesion molecule CEACAM-1 (CD66a) is not expressed in villous CTB and STB; it is strongly expressed in proximal columns, and is also observed in interstitial and endovascular trophoblasts [23, 24]. Human trophoblasts express functional L-selectin, a molecule that could play an important role during interactions between the trophoblasts and the uterine luminal epithelium [25]. Melanoma cell adhesion molecule (MCAM) is expressed by extravillous CTBs but not villous CTBs [26]. The expression of galectin-3, a mammalian lactose-binding lectin implicated during cancer progression [27], is downregulated during the first trimester of gestation, with minimal expression at 12 weeks when invasion is maximal [28]. Immunohistochemistry reveals that expression of galectin-3 is decreased when trophoblasts differentiate into cell columns [29], i.e. when CTBs acquire a migratory phenotype (fig. 3).

Placentas from preeclamptic patients are characterized by defective trophoblastic invasion and by abnormal switching of integrins. Indeed, placental bed CTBs present with a persisting expression of $\alpha 6 \beta 4$ and absence of $\alpha 1$ upregulation, suggesting that $\alpha 6 \beta 1$ integrin is expressed by placental bed CTBs as early as the late second trimester, a situation that does not exist in normal pregnancy until term [16]. Levels of plasma membrane Y397FAK are also decreased [22]. Moreover, preeclamptic CTBs fail to mimic a vascular adhesion phenotype and retain expression of $\alpha \mathrm{V} \beta 6$ and E-cadherin, and fail to upregulate $\alpha \mathrm{V} \beta 3$, VE-cadherin, VCAM-1 and PECAM-1 [30]. In in vitro experiments, preeclamptic CTBs are also characterized by reduced invasion and $\alpha 1$ integrin expression [31]. This suggests that preeclamptic trophoblasts present with an altered expression of adhesion molecules, resulting in a reduced ability to invade the decidua. 


\section{PROTEASES}

A large body of evidence demonstrates that trophoblast invasion is not due to passive mechanisms but is an active process. Indeed, trophoblasts from the first trimester of gestation are able to degrade the matrix by secreting proteases [5, 32-34]. Several types of proteases have been involved in this process, including serine proteases, cathepsins and matrix metalloproteinases. Secretion of these proteases begins already at the blastocyst stage $[35,36]$.

Human CTBs are able to invade amniotic membranes [37] and Matrigel invitro [38-40], and to digest ECM [5]. This behavior is clearly related to secreted metalloproteinases, as TIMP expression inhibits their invasiveness [37]. Gelatin zymography demonstrates that several metalloproteinases are uniquely expressed by first-trimester invasive CTBs, and not by second- and third-trimester trophoblasts [5]. Matrigel invasion by CTBs is clearly related to expression and activity of MMP-2 and MMP-9 (gelatinase B) [5, 41]. Expression and activation of MMP-9 peak during the first trimester of pregnancy at the moment when invasion is maximal [40-42].

Human extravillous CTBs acquire an invasive phenotype on Matrigel associated with a specific pattern of protease gene expression, including increased MMP-12, MT2-MMP, TIMP-2 and TIMP-3 expression, and decreased MMP-2 and TIMP-1 expression [43]. Increased expression of TIMP-3 by trophoblasts, simultaneous to that of MMP-9, provides a mechanism for controlling MMP-mediated invasion [44]. Trophoblast invasion seems also regulated by the production of MMPs and TIMPs by the maternal decidua [45]. Invasive trophoblasts produce stromelysin-3 during both, the first and third trimesters of pregnancy, but to a lesser extent during the latter [46]. STBs from the floating villi also express stromelysin-3 [46]. Plasminogen activator inhibitors or a function-perturbing antibody raised against uPA only partially inhibit CTB invasion in vitro [41]. Human trophoblast also expresses urokinase-type plasminogen activator receptor [47] that can bind active urokinasetype PA and concentrate proteolysis at the invading edge of the cells. Activity of this system is altered in preeclampsia [48]. Proteolysis of the thrombin receptor, protease-activated receptor-1 (PAR-1), is the predominant thrombin receptor on invasive extravillous trophoblast cells and may play an important role during trophoblast invasion [49]. Cathepsin B and L may also be important during trophoblast invasion [50].

Examination of preeclamptic patients reveals that their trophoblasts are characterized by reduced in vitro invasion and MMP-9 expression [31] and activation [48], and secrete less cell surface PAI [48].

\section{REGULATION OF TROPHOBLASTIC INVASION}

Trophoblastic invasion is controlled by several factors. The trophoblasts should first differentiate to anchoring trophoblasts. This is partly attributed to the contact of the trophoblast with specific, still to be characterized decidual factors, via either paracrine stimulation or direct contact with the decidual ECM [51]. This view is somewhat complicated by a recent study that examines viable tubal pregnancies [52], showing that extravillous trophoblast differentiation [defined by expression of different molecules including integrins, E-cadherin, EGF receptor (EGF-R), Ki-67 and HLA-G] was similar, except for the fact that the columns were markedly longer in tubal pregnancies [52].

\section{Steroids}

Treatment of first trimester CTBs with progesterone decreases MMP-9 expression [53].

\section{Extracellular Matrix}

Type I collagen has the ability to stimulate gelatinase secretion by CTBs [54].

\section{Hormones and Cytokines}

Placental expression of chemokines is specific to either the stromal or CTB compartment of the villi [55], suggesting that they could participate in trophoblast differentiation and invasion.

Transforming growth factor- $\beta$ produced by the decidua [56, 57], STBs and extravillous CTBs [58] induces trophoblast differentiation toward an anchoring phenotype including production of oncofetal fibronectin $[59,60]$.

The EGF-R is mainly expressed by villous CTB and STB [61], and surrounding decidual cells [62]. This receptor can bind EGF (expressed in uterine epithelial and decidual cells, and villous CTBs and STBs [63]), 
TGF- $\alpha$ (expressed in decidual cells and all trophoblast lineages [64]) and amphiregulin (expressed by STBs before 18 weeks of gestation [65]), and stimulate extravillous trophoblast proliferation [64, 66].

Production of LIF by postovulatory endometrium [67] could decrease trophoblast synthesis of human chorionic gonadotrophin (hCG), and increases oncofetal fibronectin, which suggests that it stimulates CTB differentiation towards an anchoring extravillous phenotype [68].

It has been shown that the hypoxia-inducible factor-1 $\alpha$ (HIF-1 $\alpha$ ) increases the expression of several genes important for invasion. This includes TGF- $\beta 3$, the expression profile of which is similar to that of HIF-l $\alpha[69$, 70]. This molecule is an inhibitor of the invasive extravillous phenotype of trophoblasts [70]. Preeclampsia is characterized by persistence of TGF- $\beta 3$ expression after the first trimester and trophoblasts are arrested at an intermediate immature phenotype $[69,70]$, suggesting that this anomaly is linked to the defective trophoblast invasion characteristic of the disease. Interestingly, in vitro antisense inhibition of TGF- $\beta 3$ expression or inhibition of TGF- $\beta 3$ activity with blocking antibodies induces the formation of columns of CTBs and restores their in vitro invasive phenotype [69].

Numerous hormones and cytokines are also able to modulate trophoblast invasion by modulating the expression or activity of adhesion molecules or proteases.

The cytokines IL- 1 and IL-6 increase the expression of the $\alpha 1$ and $\alpha 2$ integrin subunits in CTBs [71]. Expression of integrin $\alpha 1$ and in vitro invasion of CTBs are reduced when interfering with the binding of VEGF ligands to the CTBs [72]. Leptin, IL-1 $\alpha$, IL-6 and TGF- $\beta$ increase the expression of the $\alpha 5$ and $\alpha 6$ integrin subunits [73]. Insulin growth factor binding protein-1 (IGFBP-1), the major secretory product of the decidualized endometrium, binds the $\alpha 5 \beta 1$ integrin and stimulates cell migration [74]. Both IGF-II, which is produced by extravillous CTBs and IGFBP-1, synergistically enhance invasion of first trimester trophoblast cells [75].

MCAM expression of MCAM in JEG3 cells and trophoblast expiants is increased in the presence of human decidual tissue through PKA and cAMP pathways [26].

In vitro invasion and collagenolytic activity of the cytotrophoblastic JEG-3 cells is stimulated by hCG through a cAMP-dependent pathway [76]. Human first trimester CTB in vitro invasion is upregulated by EGF [77] and hepatocyte growth factor (HGF) from the stroma of the villi [78]. Preeclampsia is characterized by a decreased expression of HGF by the stroma of the villi [78]. Protein kinase C activators such as phorbol esters increase in vitro trophoblast invasion [38] and secretion of MMP-9 [79]. The activity of MMP-9 is upregulated by leptin and IL-1 $\alpha[73,80]$, and it is known that IL-1 concentrations in embryo culture medium are correlated with success of in vitro fertilization procedures [81].

CSF-1 present at the fetomaternal interface $[82,83]$ binds to the M-CSF receptor (M-CSF-R, the product of cfms) present on trophoblast cells since the blastocyst stage, and, later, on extravillous CTBs [83-85]. It increases cell proliferation but not invasiveness, and increases expression of both MMP-2 and TIMP-1 [86]. The expression of M-CSF-R has been correlated with trophoblast invasiveness [62].

\section{Immune System}

The placental bed contains a large population of immune cells, including uterine natural killer (NK) cells [87]. The survival of the conceptus depends on its acceptance, or nonrejection, by the maternal immune system [88]. Thus, the maternal immune system likely interacts with the process of trophoblast invasion.

For instance, HLA-G, a major histocompatibility tissue-specific antigen of low polymorphism, is expressed by invasive extravillous CTBs, including interstitial trophoblasts, placental bed giant cells and endovascular trophoblasts [89]. HLA-G1 reduces both $\mathrm{CD} 8+$ and CD4+ T cell reactivity and decreases innate immunity of uterine NK cells $[90,91]$. This could contribute to protecting invasive CTBs from attack by the uterine NK cells [92] and enables these cells to invade the uterus. In preeclampsia, expression of HLA-G is reduced or absent in extravillous CTBs [31, 93-95]. This could lead to a defective recognition of infiltrating CTBs by uterine NK cells, resulting in defective invasion and spiral artery conversion [96, 97].

A recent study demonstrates a specific profile of chemokine expression in the stromal compartment and trophoblast population of the chorionic villi, which could participate, for instance, in the recruitment of the resident macrophage (Hofbauer cell) population of the villi, CTB differentiation and invasion [55]. 


\section{Transcription Factors}

It seems that the invasive phenotype of CTBs results from the coordinated expression of gene products implicated during trophoblast invasion, such as integrins and MMPs, thus suggesting superior control by nuclear transcription factors. On the other hand, external stimuli induce intracellular signal transduction that could result in the modulation of expression and/or activity of transcription factors.

Using a transgenic mouse model system carrying homozygous gene mutations, several master regulators of trophoblast differentiation have been described [98, 99]. These transcription factors include Hand1, Mash2, Id2, E-factor, I-mfa, GCM1 and Sta13. Descriptive studies have shown that several of these factors are also expressed in the human placenta, suggesting that the mechanisms controlling trophoblast differentiation could be similar in mice and men. A chapter in this book is dedicated to this topic.

Several transcription factors have already been examined. For instance, the promoter site of MMP-1, MMP-3 and MMP-9 is able to bind the AP-1 complex, a heterodimer of Jun and Fos, which is thought to be important during the mediation of signals that lead to increased MMP expression. Indeed, the AP-1 complex is implicated in the MMP-1 response to IL-1, TNF and TGF- $\beta[34,62]$ and in the MMP-3 regulation by PDGF and TGF- $\beta$ $[34,62]$. Both Fos and Jun are highly expressed in human trophoblast [100]. Moreover, the effects of EGF on trophoblast proliferation and differentiation depend on modulation of c-fos and c-jun expression [101]. Jun-B is essential for the establishment of vascular connections with the maternal circulation during mouse placentation $[102]$.

The transcription factor c-myc activates telomerase by interaction with the hTERT (telomerase reverse transcriptase) promoter [103] and seems essential for progression of the cell cycle. The expression of c-myc correlates with early trophoblast proliferation [104]. Moreover, expression of c-myc colocalizes with expression of c-sis, which encodes for the $\beta$ chain of PDGF, and is thought to participate in the control of proliferation of trophoblasts [105].

An important transcription factor for placentation is the HIF-1 protein complex [106, 107], which binds a short DNA motif located in the 5'-flanking regions of various hypoxia-induced genes [108]. HIF-1 binds DNA as a heterodimer composed of 2 subunits, the constitutively expressed HIF-1 $\beta$ (aryl hydrocarbon receptor nuclear translocator, ARNT) and HIF-1 $\alpha$, which is induced in hypoxic conditions and is quickly degraded by the proteasome under normoxic conditions through an interaction with the von Hippel-Lindau tumor suppressor protein (pVHL) [109]. Trophoblasts grown under hypoxic conditions are used to model the cellular environment of normal and preeclamptic gestation $[110,111]$. Indeed, normoxic CTBs differentiate towards an invasive phenotype, which allows them to invade Matrigel [5, 41], as observed in invasive intermediate trophoblasts that are in a hypoxic environment. Hypoxic conditions $\left(2 \% \mathrm{O}_{2}\right)$ induce trophoblast proliferation, increase fibronectin synthesis, expression of $\alpha 5$ integrin, gelatinase A activity, and inhibit invasion, due at least in part to their inability to switch their integrin repertoire, such as induction of $\alpha 1 \beta 1[70,110]$. This is thought to reflect the behavior of trophoblasts that have invaded the maternal bloodstream, are in contact with oxygenated blood and have decreased their invasive phenotype. These phenotypical changes could be related to the modulated expression of HIF-1. Indeed, expression of HIF-1 $\alpha$ is high during the first trimester of gestation, decreases after 9 weeks when placental $\mathrm{pO}_{2}$ levels are believed to increase, and is absent at 11-14 weeks and afterwards [70]. This observation fits with the hypothesis that the placental environment is hypoxic during the first trimester of gestation until invasive CTBs invade the uterine arteries [112-115]. The expression of pVHL, implicated in initiating the degradation of HIF-1 $\alpha$, is highly expressed at sites of column initiation and is increased by hypoxia [116].

\section{CONCLUSIONS}

A large body of literature is now available to better explain the molecular mechanisms of trophoblastic invasion. However, important questions still remain unanswered, and need further investigation. Understanding trophoblast invasion could also provide insights into the pathogenesis of preeclampsia. These data could constitute the basis for new therapeutic strategies for this disease.

\section{Acknowledgments}

Our work on human placenta and trophoblast invasion is supported by the National Fund for Scientific Research 
(NFSR), Belgium, the 'Fonds Spéciaux de la Recherche', the Centre Anticancéreux près l'Université de Liège, the Fondation Léon Frédéricq of the University of Liège, Belgium, and the Fonds d'Investissement pour la Recherche Scientifique (FIRS) of the Centre Hospitalier Universitaire de Liège (Belgique).

Frédéric van den Brûle is a Senior Research Associate, Sarah Berndt is the beneficiary of aTelevie grant, and Carine Munaut is a Research Associate of the NFSR (Belgium).

Several authors of this manuscript are members of an European Network of Excellence, entitled 'EMBIC (Embryo Implantation Control), supported by the European Union (contract no. 512040).

\section{References}

1 Hertig AT, Rock J, Adams EC, Menkin MC: Thirty-four fertilized human ova, good, bad and indifferent, recovered from 210 women of known fertility; a study of biologic wastage in early human pregnancy. Pediatrics 1959;23:202-211.

2 Brosens I, Dixon HG: The anatomy of the maternal side of the placenta. J Obstet Gynaecol Br Commonw 1966;73:357-363.

3 EndersAC: Fine structure of anchoring villi of the human placenta. Am J Anat $1968 ; 122: 419-451$.

4 Enders AC: Cytology of human early implantation. Res Reprod 1976;8:1-2.

5 Fisher SJ, Cui TY, Zhang L, Hartman L, Grahl K, Zhang GY, Tarpey J, Damsky CH: Adhesive and degradative properties of human placental cytotrophoblast cells in vitro. J Cell Biol 1989; 109:891-902.

6 Pijnenborg R, Bland JM, Robertson WB, Dixon G, Brosens I: The pattern of interstitial trophoblastic invasion of the myometrium in early human pregnancy. Placenta 1981;2:303-316.

7 Kurman RJ, Main CS, Chen HC: Intermediate trophoblast: A distinctive form of trophoblast with specific morphological, biochemical and functional features. Placenta 1984;5:349-369.

8 Yeh IT, Kurman RJ: Functional and morphologic expressions of trophoblast. Lab Invest 1989; 61:1—4.

9 Pijnenborg R, Robertson WB, Brosens I, Dixon G: Review article: Trophoblast invasion and the establishment of haemochorial placentation in man and laboratory animals. Placenta 1981; 2:71-91.

10 Pijnenborg R, Bland JM, Robertson WB, Brosens I: Uteroplacental arterial changes related to interstitial trophoblast migration in early human pregnancy. Placenta 1983;4:397-413.

11 Liotta LA, Rao CN, Wewer UM: Biochemical interactions of tumor cells with the basement membrane. Annu Rev Biochem $1986 \cdot 55: 1037-1057$

12 Norwitz ER, Schust DJ, Fisher SJ: Implantation and the survival of early pregnancy. N Engl J Med 2001;345:1400-1408.

13 Shih IM, Kurman RJ: New concepts in trophoblastic growth and differentiation with practical application for the diagnosis of gestational trophoblastic disease. Verh Dtsch Ges Pathol 1997; 81:266-272.

14 Damsky CH, Fitzgerald ML, Fisher SJ: Distribution patterns of extracellular matrix components and adhesion receptors are intricately modulated during first trimester cytotrophoblast differentiation along the invasive pathway, in vivo. J Clin Invest 1992;89:210-222.

15 Damsky CH, Librach C, Lim KH, Fitzgerald ML, McMaster MT, Janatpour M, Zhou Y, Logan SK, Fisher SJ: Integrin switching regulates normal trophoblast invasion. Development 1994;120: 3657-3666.

16 Zhou Y, Damsky CH, Chiu K, Roberts JM, Fisher SJ: Preeclampsia is associated with abnormal expression of adhesion molecules by invasive cytotrophoblasts. J Clin Invest 1993;91:950-960.

17 Zhou Y, Fisher SJ, Janatpour M, Genbacev O, DejanaE, Wheelock M, Damsky CH: Human cytotrophoblasts adopt a vascular phenotype as they differentiate. A strategy for successful endovascular invasion? J Clin Invest 1997;99:2139-2151.

18 Zhou Y, Genbacev O, Damsky CH, Fisher SJ: Oxygen regulates human cytotrophoblast differentiation and invasion: Implications for endovascular invasion in normal pregnancy and in preeclampsia. J Reprod Immunol 1998;39:197-213.

19 Damsky CH, Fisher SJ: Trophoblast pseudo-vasculogenesis: Faking it with endothelial adhesion receptors. Curr Opin Cell Biol 1998;10:660-666.

20 Murray MJ, Lessey BA: Embryo implantation and tumor metastasis: Common pathways of invasion and angiogenesis. Semin Reprod Endocrinol 1999; 17:275-290. 
21 Hemberger M, Nozaki T, Masutani M, Cross JC: Differential expression of angiogenic and vasodilatory factors by invasive trophoblast giant cells depending on depth of invasion. Dev Dyn 2003;227:185-191.

22 Ilic D, Genbacev O, Jin F, Caceres E, Almeida EA, Bellingard-Dubouchaud V, Schaefer EM, Damsky CH, Fisher SJ: Plasma membrane-associated pY397FAK is a marker of cytotrophoblast invasion in vivo and in vitro. Am J Pathol 2001;159:93-108.

23 Bamberger AM, Sudahl S, Loning T, Wagener C, Bamberger CM, Drakakis P, Coutifaris C, Makrigiannakis A: The adhesion molecule CEACAM1 (CD66a, C-CAM, BGP) is specifically expressed by the extravillous intermediate trophoblast. Am J Pathol 2000;156:1165-1170

24 Bamberger AM, Sudahl S, Wagener C, Loning T: Expression pattern of the adhesion molecule CEACAM1 (C-CAM, CD66a, BGP) in gestational trophoblastic lesions. Int J Gynecol Pathol 2001;20:160-165.

25 Genbacev OD, Prakobphol A, Foulk RA, Krtolica AR, Ilic D, Singer MS, Yang ZQ, Kiessling LL, Rosen SD, Fisher SJ: Trophoblast L-selectin-mediated adhesion at the maternal-fetal interface. Science 2003;299:405-408.

26 Higuchi T, Fujiwara H, Egawa H, Sato Y, Yoshioka S, Tatsumi K, Itoh K, Maeda M, Fujita J, Fujii S: Cyclic AMP enhances the expression of an extravillous trophoblast marker, melanoma cell adhesion molecule, in choriocarcinoma cell JEG3 and human chorionic villous expiant cultures. Mol Hum Reprod 2003;9:359-366.

27 van den Brûle F, Califice S, Castronovo V: Expression of galectins in cancer: A critical review. Glycoconj J 2004;19:537-542.

28 van den Brûle FA, Price J, Sobel ME, Lambotte R, Castronovo V: Inverse expression of two laminin binding proteins, 67LR and galectin-3, correlates with the invasive phenotype of trophoblastic tissue. Biochem Biophys Res Commun 1994;201:388-393.

29 Maquoi E, van den Brûle FA, Castronovo V, Foidart JM: Changes in the distribution pattern of galectin-1 and galectin-3 in human placenta correlates with the differentiation pathways of trophoblasts. Placenta 1997;18:433-439.

30 Zhou Y, Damsky CH, Fisher SJ: Preeclampsia is associated with failure of human cytotrophoblasts to mimic a vascular adhesion phenotype. One cause of defective endovascular invasion in this syndrome? J Clin Invest 1997;99:2152-2164.

31 Lim KH, Zhou Y, Janatpour M, McMaster M, Bass K, Chun SH, Fisher SJ: Human cytotrophoblast differentiation/invasion is abnormal in pre-eclampsia. Am J Pathol 1997; 151:1809-1818.

32 Fisher SJ, Leitch MS, Kantor MS, Basbaum CB, Kramer RH: Degradation of extracellular matrix by the trophoblastic cells of firsttrimester human placentas. J Cell Biochem 1985;27:31-41.

33 Bischof P, Martelli M: Current topic: Proteolysis in the penetration phase of the implantation process. Placenta 1992;13:17-24.

34 Bischof P, Martelli M, Campana A, ItohY, Ogata Y, Nagase H: Importance of matrix metallopro-teinases in human trophoblast invasion. Early Pregnancy 1995;1:263-269.

35 Puistola U, Ronnberg L, Martikainen H, Turpeenniemi-Hujanen T: The human embryo produces basement membrane collagen (type IV collagen)-degrading protease activity. Hum Reprod 1989; 4:309-311.

36 Huppertz B, Kertschanska S, Demir AY, Frank HG, Kaufmann P: Immunohistochemistry of matrix metalloproteinases (MMP), their substrates, and their inhibitors (TIMP) during trophoblast invasion in the human placenta. Cell Tissue Res 1998;291:133-148.

37 Yagel S, Parhar RS, Jeffrey JJ, Lala PK: Normal nonmetastatic human trophoblast cells share invitro invasive properties of malignant cells. J Cell Physiol 1988;136:455-462.

38 Kliman HJ, Feinberg RF: Human trophoblast-extracellular matrix (ECM) interactions in vitro: ECM thickness modulates morphology and proteolytic activity. Proc Natl Acad Sci USA 1990; 87:3057-3061.

39 Graham CH, Connelly I, MacDougall JR, Kerbel RS, Stetler-Stevenson WG, Lala PK: Resistance of malignant trophoblast cells to both the anti-proliferative and anti-invasive effects of transforming growth factor-beta. Exp Cell Res 1994;214:93-99.

40 Shimonovitz S, Hurwitz A, Dushnik M, Anteby E, Geva-Eldar T, Yagel S: Developmental regulation of the expression of 72 and 92 kd type IV collagenases in human trophoblasts: A possible mechanism for control of trophoblast invasion. Am J Obstet Gynecol $1994 ; 171: 832-838$

41 Librach CL, Werb Z, Fitzgerald ML, Chiu K, Corwin NM, Esteves RA, Grobelny D, Galardy R, Damsky CH, Fisher SJ: 92-kD type IV collagenase mediates invasion of human cytotrophoblasts. J Cell Biol 1991;113:437-449.

42 Cross JC, Werb Z, Fisher SJ: Implantation and the placenta: Key pieces of the development puzzle. Science 1994;266:1508-1518.

43 Tarrade A, Goffin F, Munaut C, Lai-Kuen R, Tricottet V, Foidart JM, Vidaud M, Frankenne F, Evain-Brion D: Effect of matrigel on human extravillous trophoblasts differentiation: Modulation of protease pattern gene expression. Biol Reprod 2002;67:1628-1637. 
44 Bass KE, Li H, Hawkes SP, Howard E, Bullen E, Vu TK, McMaster M, Janatpour M, Fisher SJ: Tissue inhibitor of metalloproteinase3 expression is upregulated during human cytotrophoblast invasion in vitro. Dev Genet 1997;21:61-67.

45 Schatz F, Krikun G, Runic R, Wang EY, Hausknecht V, Lockwood CJ: Implications of decidualization-associated protease expression in implantation and menstruation. Semin Reprod Endocrinol 1999;17:3-12.

46 Maquoi E, Polette M, Nawrocki B, Bischof P, Noel A, Pintiaux A, Santavicca M, Schaaps JP, Pijnenborg R, Birembaut P, Foidart JM: Expression of stromelysin-3 in the human placenta and placental bed. Placenta 1997;18:277-285.

47 Zini JM, Murray SC, Graham CH, Lala PK, Kariko K, Bamathan ES, Mazar A, Henkin J, Cities DB, McCrae KR: Characterization of urokinase receptor expression by human placental trophoblasts. Blood 1992;79:2917-2929.

48 Graham $\mathrm{CH}, \mathrm{McCrae} \mathrm{KR}$ : Altered expression of gelatinase and surface-associated plasminogen activator activity by trophoblast cells isolated from placentas of preeclamptic patients. Am J Obstet Gynecol 1996;175:555-562.

49 O'Brien PJ, Koi H, Parry S, Brass LF, Strauss JF 3rd, Wang LP, Tomaszewski JE, Christenson LK: Thrombin receptors and proteaseactivated receptor-2 in human placentation: Receptor activation mediates extravillous trophoblast invasion in vitro. Am $\mathrm{J}$ Pathol 2003; 163: 1245-1254.

50 Afonso S, Romagnano L, Babiarz B: The expression and function of cystatin C and cathepsin B and cathepsin L during mouse embryo implantation and placentation. Development 1997; 124: 3415-3425.

51 Vicovac L, Jones CJ, Aplin JD: Trophoblast differentiation during formation of anchoring villi in a model of the early human placenta in vitro. Placenta 1995;16:41-56.

52 Goffin F, Munaut C, Malassine A, Evain-Brion D, Frankenne F, Fridman V, Dubois M, Uzan S, Merviel P, Foidart JM: Evidence of a limited contribution of feto-maternal interactions to trophoblast differentiation along the invasive pathway. Tissue Antigens 2003;62:104116.

53 Shimonovitz S, Hurwitz A, Hochner-Celnikier D, Dushnik M, Anteby E, Yagel S: Expression of gelatinase B by trophoblast cells: Down-regulation by progesterone. Am J Obstet Gynecol 1998; 178:457-461.

54 Emonard H, Christiane Y, Smet M, Grimaud JA, Foidart JM: Type IV and interstitial collagenolytic activities in normal and malignant trophoblast cells are specifically regulated by the extracellular matrix. Invasion Metastasis 1990;10:170-177.

55 Drake PM, Red-Horse K, Fisher SJ: Reciprocal chemokine receptor and ligand expression in the human placenta: Implications for cytotrophoblast differentiation. Dev Dyn 2004;229:877-885.

56 Graham CH, Lysiak JJ, McCrae KR, Lala PK: Localization of transforming growth factor-beta at the human fetal-maternal interface: Role in trophoblast growth and differentiation. Biol Reprod 1992;46:561-572.

57 Hofmann GE, Horowitz GM, Scott RT Jr, Navot D: Transforming growth factor-alpha in human implantation trophoblast: Immunohistochemical evidence for autocrine/paracrine function. J Clin Endocrinol Metab 1993;76:781-785.

58 Lysiak JJ, Hunt J, Pringle GA, Lala PK: Localization of transforming growth factor beta and its natural inhibitor decorin in the human placenta and decidua throughout gestation. Placenta 1995; 16:221-231.

59 Feinberg RF, Kliman HJ, Wang CL: Transforming growth factor-beta stimulates trophoblast oncofetal fibronectin synthesis in vitro: Implications for trophoblast implantation in vivo. J Clin Endocrinol Metab 1994;78:1241-1248.

$60 \mathrm{Xu} \mathrm{G}$, Guimond MJ, Chakraborty C, Lala PK: Control of proliferation, migration, and invasiveness of human extravillous trophoblast by decorin, a decidual product. Biol Reprod 2002;67: 681-689.

61 Jokhi PP, King A, Loke YW: Reciprocal expression of epidermal growth factor receptor (EGF-R) and c-erbB2 by non-invasive and invasive human trophoblast populations. Cytokine 1994;6: 433-442.

62 Bischof P, Campana A: Trophoblast differentiation and invasion: Its significance for human embryo implantation. Early Pregnancy 1997;3:81-95.

63 Hofmann GE, Scott RT Jr., Bergh PA, Deligdisch L: Immunohistochemical localization of epidermal growth factor in human endometrium, decidua, and placenta. J Clin Endocrinol Metab 1991; 73:882-887.

64 Lala PK, Hamilton GS: Growth factors, proteases and protease inhibitors in the maternal-fetal dialogue. Placenta 1996;17:545-555.

65 Lysiak JJ, Johnson GR, Lala PK: Localization of amphiregulin in the human placenta and decidua throughout gestation: Role in trophoblast growth. Placenta 1995;16:359-366.

66 Li RH, Zhuang LZ: The effects of growth factors on human normal placental cytotrophoblast cell proliferation. Hum Reprod $1997 ; 12: 830-834$ 
67 Cullinan EB, Abbondanzo SJ, Anderson PS, Pollard JW, Lessey BA, Stewart CL: Leukemia inhibitory factor (LIF) and LIF receptor expression in human endometrium suggests a potential autocrine/paracrine function in regulating embryo implantation. Proc Natl Acad Sci USA 1996; 93:3115-3120.

68 Nachtigall MJ, Kliman HJ, Feinberg RF, Olive DL, Engin O, Arici A: The effect of leukemia inhibitory factor (LIF) on trophoblast differentiation: A potential role in human implantation. J Clin Endocrinol Metab 1996;81:801-806.

69 Caniggia I, Grisaru-Gravnosky S, Kuliszewsky M, Post M, Lye SJ: Inhibition of TGF-beta 3 restores the invasive capability of extravillous trophoblasts in preeclamptic pregnancies. J Clin Invest 1999;103:1641-1650.

70 Caniggia I, Mostachfi H, Winter J, Gassmann M, Lye SJ, Kuliszewski M, Post M: Hypoxia-inducible factor-1 mediates the biological effects of oxygen on human trophoblast differentiation through TGFbeta(3). J Clin Invest 2000;105:577-587.

71 Das C, Kumar VS, Gupta S, Kumar S: Network of cytokines, integrins and hormones in human trophoblast cells. J Reprod Immunol 2002;53:257-268.

72 Zhou Y, McMaster M, Woo K, Janatpour M, Perry J, Karpanen T, Alitalo K, Damsky C, Fisher SJ: Vascular endothelial growth factor ligands and receptors that regulate human cytotrophoblast survival are dysregulated in severe preeclampsia and hemolysis, elevated liver enzymes, and low platelets syndrome. Am J Pathol 2002;160:1405-1423.

73 Gonzalez RR, Devoto L, Campana A, Bischof P: Effects of leptin, interleukin-1 alpha, interleukin-6, and transforming growth factorbeta on markers of trophoblast invasive phenotype: Integrins and metalloproteinases. Endocrine 2001;15:157-164.

74 Jones JI, Gockerman A, Busby WH Jr, Wright G, Clemmons DR: Insulin-like growth factor binding protein 1 stimulates cell migration and binds to the alpha 5 beta 1 integrin by means of its Arg-Gly-Asp sequence. Proc Natl Acad Sci USA 1993;90:10553-10557.

75 Han VK, Bassett N, Walton J, Challis JR: The expression of insulin-like growth factor (IGF) and IGF-binding protein (IGFBP) genes in the human placenta and membranes: Evidence for IGF-IGFBP interactions at the feto-maternal interface. J Clin Endocrinol Metab 1996;81:2680-2693.

76 Zygmunt M, Hahn D, Munstedt K, Bischof P, Lang U: Invasion of cytotrophoblastic JEG-3 cells is stimulated by hCG in vitro. Placenta 1998;19:587-593.

77 Bass KE, Morrish D, Roth I, Bhardwaj D, Taylor R, Zhou Y, Fisher SJ: Human cytotrophoblast invasion is up-regulated by epidermal growth factor: Evidence that paracrine factors modify this process. Dev Biol 1994;164:550-561.

78 Nasu K, Zhou Y, McMaster MT, Fisher SJ: Upregulation of human cytotrophoblast invasion by hepatocyte growth factor. J Reprod Fertil Suppl 2000;55:73-80

79 Sawicki G, Radomski MW, Winkler-Lowen B, Krzymien A, Guilbert LJ: Polarized release of matrix metalloproteinase-2 and -9 from cultured human placental syncytiotrophoblasts. Biol Reprod 2000;63:1390-1395.

80 Librach CL, Feigenbaum SL, Bass KE, Cui TY, Verastas N, Sadovsky Y, Quigley JP, French DL, Fisher S J: Interleukin-1 beta regulates human cytotrophoblast metalloproteinase activity and invasion in vitro. J Biol Chem 1994;269:17125-17131.

81 Sheth KV, Roca GL, al-Sedairy ST, Parhar RS, Hamilton CJ, al-Abdul Jabbar F: Prediction of successful embryo implantation by measuring interleukin-1-alpha and immunosuppressive factor(s) in preimplantation embryo culture fluid. Fertil Steril 1991;55:952-957.

82 Pollard JW, Bartocci A, Arceci R, Orlofsky A, Ladner MB, Stanley ER: Apparent role of the macrophage growth factor, CSF-1, in placental development. Nature 1987;330:484-486.

83 Jokhi PP, Chumbley G, King A, Gardner L, Loke YW: Expression of the colony stimulating factor-1 receptor (c-fms product) by cells at the human uteroplacental interface. Lab Invest 1993; 68:308-320.

84 Hoshina M, Nishio A, Bo M, Boime I, Mochizuki M: The expression of oncogene fms in human chorionic tissue. Nippon Sanka Fujinka Gakkai Zasshi 1985;37:2791-2798.

85 Sharkey AM, Dellow K, Blayney M, Macnamee M, Charnock-Jones S, Smith SK: Stage-specific expression of cytokine and receptor messenger ribonucleic acids in human preimplantation embryos. Biol Reprod 1995;53:974-981.

86 Hamilton GS, Lysiak JJ, Watson AJ, Lala PK: Effects of colony stimulating factor-1 on human extravillous trophoblast growth and invasion. J Endocrinol 1998;159:69-77.

87 Moffett-King A: Natural killer cells and pregnancy. Nat Rev Immunol 2002;2:656-663.

88 Moffert A, Loke YW: The immunological paradox of pregnancy: A reappraisal. Placenta 2004; 25:1-8.

89 Le Bouteiller P, Solier C, Proll J, Aguerre-Girr M, Fournel S, Lenfant F: Placental HLA-G protein expression in vivo: Where and what for? Hum Reprod Update 1999;5:223-233. 
Published in : Chemical Immunology and Allergy (2005), vol. 88, pp 163-80

Status : Postprint (Author's version)

90 Rouas-Freiss N, Marchai RE, Kirszenbaum M, Dausset J, Carosella ED: The alphal domain of HLA-G1 and HLA-G2 inhibits cytotoxicity induced by natural killer cells: Is HLA-G the public ligand for natural killer cell inhibitory receptors? Proc Natl Acad Sci USA 1997;94:5249-5254.

91 Le Bouteiller P, Pizzato N, Barakonyi A, Solier C: HLA-G, pre-eclampsia, immunity and vascular events. J Reprod Immunol 2003;59:219-234.

92 Navarro F, Llano M, Bellon T, Colonna M, Geraghty DE, Lopez-Botet M: The ILT2(LIR1) and CD94/NKG2A NK cell receptors respectively recognize HLA-G1 and HLA-E molecules co-expressed on target cells. Eur J Immunol 1999;29:277-283.

93 Colbern GT, Chiang MH, Main EK: Expression of the nonclassic histocompatibility antigen HLA-G by preeclamptic placenta. Am J Obstet Gynecol 1994;170:1244-1250.

94 Hara N, Fujii T, Yamashita T, Kozuma S, Okai T, Taketani Y: Altered expression of human leukocyte antigen G (HLA-G) on extravillous trophoblasts in preeclampsia: Immunohistological demonstration with anti-HLA-G specific antibody '87G' and anti-cytokeratin antibody 'CAM5.2'. Am J Reprod Immunol 1996;36:349-358

95 Goldman-Wohl DS, Ariel I, Greenfield C, Hochner-Celnikier D, Cross J, Fisher S, Yagel S: Lack of human leukocyte antigen-G expression in extravillous trophoblasts is associated with preeclampsia. Mol Hum Reprod 2000;6:88-95.

96 Dekker GA, Sibai BM: Etiology and pathogenesis of preeclampsia: Current concepts. Am J Obstet Gynecol 1998;179:1359-1375.

97 Thellin O, Coumans B, Zorzi W, Igout A, Heinen E: Tolerance to the foeto-placental 'graft': Ten ways to support a child for nine months. Curr Opin Immunol 2000;12:731-737.

98 Cross JC: Genetic insights into trophoblast differentiation and placental morphogenesis. Semin Cell Dev Biol 2000;11:105-113.

99 Loregger T, Pollheimer J, Knofler M: Regulatory transcription factors controlling function and differentiation of human trophoblast - a review. Placenta 2003;24(suppl A):S104-S110.

100 Doneda L, Bulfamante G, Grimoldi MG, Volpi L, Larizza L: Localization of fos, jun, kit and SCF mRNA in human placenta throughout gestation using in situ RT-PCR. Early Pregnancy 1997; 3:265-271.

101 Dakour J, Li H, Chen H, Morrish DW: EGF promotes development of a differentiated trophoblast phenotype having c-myc and junB proto-oncogene activation. Placenta 1999;20:119-126.

102 Schorpp-Kistner M, Wang ZQ, Angel P, Wagner EF: JunB is essential for mammalian placentation. EMBO J 1999;18:934-948.

103 Wu KJ, Grandori C, Amacker M, Simon-Vermot N, Polack A, Lingner J, Dalla-Favera R: Direct activation of TERT transcription by c-MYC. Nat Genet 1999;21:220-224.

104 Pfeifer-Ohlsson S, Goustin AS, Rydnert J, Wahlstrom T, Bjersing L, Stehelin D, Ohlsson R: Spatial and temporal pattern of cellular myc oncogene expression in developing human placenta: Implications for embryonic cell proliferation. Cell 1984;38:585-596

105 Goustin AS, Betsholtz C, Pfeifer-Ohlsson S, Persson H, Rydnert J, Bywater M, Holmgren G, Heldin CH, Westermark B, Ohlsson R: Coexpression of the sis and myc proto-oncogenes in developing human placenta suggests autocrine control of trophoblast growth. Cell $1985 ; 41: 301-312$

106 Wenger RH, Gassmann M: Oxygen(es) and the hypoxia-inducible factor-1. Biol Chem 1997; 378:609-616.

107 Wang GL, Semenza GL: General involvement of hypoxia-inducible factor 1 in transcriptional response to hypoxia. Proc Natl Acad Sci USA 1993;90:4304-4308.

108 Wang GL, Jiang BH, Rue EA, Semenza GL: Hypoxia-inducible factor 1 is a basic-helix-loop-helix-PAS heterodimer regulated by cellular $\mathrm{O}_{2}$ tension. Proc Natl Acad Sci USA 1995;92: 5510-5514.

109 Maxwell PH, Wiesener MS, Chang GW, Clifford SC, Vaux EC, Cockman ME, Wykoff CC, Pugh CW, Maher ER, Ratcliffe PJ: The tumour suppressor protein VHL targets hypoxia-inducible factors for oxygen-dependent proteolysis. Nature 1999;399:271-275.

110 Genbacev O, Joslin R, Damsky CH, Polliotti BM, Fisher S J: Hypoxia alters early gestation human cytotrophoblast differentiation/invasion in vitro and models the placental defects that occur in preeclampsia. J Clin Invest 1996;97:540-550.

111 Genbacev O, Zhou Y, Ludlow JW, Fisher SJ: Regulation of human placental development by oxygen tension. Science $1997 ; 277: 1669-1672$

112 Hustin J, Schaaps JP: Echographic [corrected] and anatomic studies of the maternotrophoblastic border during the first trimester of pregnancy. Am J Obstet Gynecol 1987;157:162-168.

113 Rodesch F, Simon P, Donner C, Jauniaux E: Oxygen measurements in endometrial and trophoblastic tissues during early pregnancy. 
Published in : Chemical Immunology and Allergy (2005), vol. 88, pp 163-80 Status : Postprint (Author's version)

Obstet Gynecol 1992;80:283-285

114 Burton GJ, Jauniaux E, Watson AL: Maternal arterial connections to the placental intervillous space during the first trimester of human pregnancy: The Boyd collection revisited. Am J Obstet Gynecol 1999;181:718-724.

115 Jauniaux E, Watson AL, Hempstock J, Bao YP, Skepper JN, Burton GJ: Onset of maternal arterial blood flow and placental oxidative stress. A possible factor in human early pregnancy failure. Am J Pathol 2000;157:2111-2122.

116 Genbacev O, Krtolica A, Kaelin W, Fisher SJ: Human cytotrophoblast expression of the von Hippel-Lindau protein is downregulated during uterine invasion in situ and upregulated by hypoxia in vitro. Dev Biol 2001;233:526-536.

117 Proll J, Blaschitz A, Hartmann M, Thalhamer J, Dohr G: Human first-trimester placenta intra-arterial trophoblast cells express the neural cell adhesion molecule. Early Pregnancy 1996;2:271-275. 